Original Article

\title{
THE OPTIMIZATION OF RP-HPLC CONDITION USING RESPONSE SURFACE METHODOLOGY BOX- BEHNKEN DESIGN FOR SIMULTANEOUS DETERMINATION OF METFORMIN HCL AND GLIMEPIRIDE IN SPIKED PLASMA
}

\author{
HAYATUN IZMA², SUDIBYO MARTONO ${ }^{2}$, ENDANG LUKITANINGSIH'* \\ ${ }^{1}$ Department of Pharmaceutical Chemistry, Faculty of Pharmacy, Universitas Gadjah Mada, Jl. Sekip Utara, Yogyakarta, 55281, \\ Indonesia, ${ }^{2}$ Master Program, Faculty of Pharmacy, Universitas Gadjah Mada, Jl. Sekip Utara, Yogyakarta, 55281, Indonesia \\ Email: lukitaningsih_end@ugm.ac.id
}

Received: 12 Oct 2019, Revised and Accepted: 10 Dec 2019

\section{ABSTRACT}

Objective: Aim of this study was to develop and validate the RP-HPLC method using Box-Behnken Design (BBD) for simultaneous analysis metformin $\mathrm{HCl}$ and glimepiride in spiked plasma.

Methods: The chromatographic system was comprised of acetonitrile-phosphate buffer 0.0125 M+Sodium Dodecyl Sulphate (SDS) 1 mmol as a mobile phase and Ascentis ${ }^{\circledR}$ Phenyl C18 (250 x $4.6 \mathrm{~mm}$ i.d.; $5 \mu \mathrm{m}$ ) column as a stationary phase with UV detector at $210 \mathrm{~nm}$. Three independent variables included phosphate buffer (\%), $\mathrm{pH}$ and flow rate were optimized using Box-Behnken Design. The observed responses were retention time, peak area and resolution.

Results: The predicted optimum condition of the RP-HPLC system consisted of phosphate buffer solution of $72 \%$, pH at 4.3 and flow rate at 0.8 $\mathrm{ml} / \mathrm{min}$. By using this condition, the duration of analysis was more than $18 \mathrm{~min}$, so it was necessary to modify the flow rate to be $1.0 \mathrm{ml} / \mathrm{min}$ to get shorter analysis duration. This condition was then applied to analyze metformin and glimepiride in spiked plasma and validated according to the EMA guideline. AUC of interfering components at the IS retention time between 588-1092 mV, the linearity of metformin was 0.9993 and glimepiride was 0.9991 , accuracy and precision were between-13.33\% until $16.08 \%$, dilution integrity and metformin stability studies were between-4.01\% until 11.82\%, and for glimepiride stability studies were between-37.48\% until-4.76\%

Conclusion: Box-Behnken Design can help optimize the HPLC system, and the optimum condition was valid to analyze metformin and glimepiride in spiked plasma by considering the storage time of plasma samples.

Keywords: Metformin HCl, Glimepiride, RP-HPLC, Spiked plasma, Box-Behnken Design

(C) 2020 The Authors. Published by Innovare Academic Sciences Pvt Ltd. This is an open-access article under the CC BY license (http://creativecommons.org/licenses/by/4.0/] DOI: http://dx.doi.org/10.22159/ijap.2020v12i2.36052. Journal homepage: https://innovareacademics.in/journals/index.php/ijap

\section{INTRODUCTION}

Diabetes mellitus (DM) is one of the 10 causes of death in the world [1-2]. Monotherapy for patients with type 2 diabetes has often a failure to control glucose levels. Therefore, a combination therapy required to achieve target glycaemic goals [3]. A combination of metformin and sulfonylurea has been attached in many cases and indicates highly effective to control of glucose levels [4]. The uses of glimepiride as the second generation of sulphonylurea have some benefit in the effectivity in low dose, long duration, and the lower risk in older patients [5-6]. Monitoring and evaluation of the plasma level of these drugs are crucial for individual dose, pharmacokinetics as well as in bioequivalence studies [7-9].

Plasma is a biological sample that extremely complex matrices composed of many components that can disrupt the quantitative measurement of the drugs [10]. Therefore, high selectivity and sensitivity analytical method is needed. Various methods using HPLC and LC-MS/MS have been expands for the simultaneous quantification of metformin and glimepiride in plasma matrices [1119]. HPLC is one of the selected methods for analysis in this study, it is widely used for pharmaceutical analysis or bioanalysis and available in almost all analytical chemistry laboratories [20].<smiles>CCC1=C(C)CN(C(=O)NCCc2ccc(S(=O)(=O)NC(=O)N[C@H]3CC[C@H](C)CC3)cc2)C1=O</smiles>

(A)<smiles>CC(C)NCC(O)COc1ccc(CC(N)=O)cc1</smiles>

(C)

Fig. 1: The chemical structure of metformin (A), glimepiride (B), and atenolol as internal standar (C) 
Some parameters like the percentage of buffer solution in the mobile phase, $\mathrm{pH}$ and flow rate have a major effect on HPLC separation [21] Box-Behnken Design is a multivariate analysis technique that can minimize the time and costs for the optimization process [22-24]. It was applied to various studies, like the isolation process, development of drug formulation, and optimization of chromatographic conditions [25-27]. Optimization of HPLC conditions using BBD has been applied for the analysis of various samples [28-30]. The predicted condition of HPLC obtained using BBD was applied for the simultaneous analysis of metformin and glimepiride in plasma and then was validated according to European Medicines Agency (EMA) guidelines.

\section{MATERIALS AND METHODS}

\section{Reagents and materials}

Metformin working standard $(99.5 \%$ purity; PT. Phapros, Tbk, Indonesia), glimepiride working standard (100.49\% purity; PT. Phapros, Tbk., Indonesia), and atenolol reference standard (Sigma Aldrich, France), distilled water (PT. Brataco, Indonesia), acetonitrile HPLC grade (J. T. Baker, New Jersey), potassium dihydrogen phosphate p. a, sodium dodecyl sulphate (SDS) for ion pair chromatography (Sigma Aldrich France), and blank human plasma collected from the Indonesian Red Cross in Yogyakarta-Indonesia was stored at- $20^{\circ} \mathrm{C}$ until use.

\section{HPLC condition}

The LC system used for analysis was consisted of Hitachi UV-Vis L2420 detector (at $210 \mathrm{~nm}$ ), Hitachi L-2130 HPLC pump, D-2000 HSM elite software, chromatographic column Ascentis ${ }^{\circledR}$ Phenyl C18 (250 x $4.6 \mathrm{~mm}$ i.d.; $5 \mu \mathrm{m}$ ), and injection valve with a $20 \mu \mathrm{l}$ loop. The mobile phase was composed of acetonitrile and phosphate buffer $0.0125 \mathrm{M}+\mathrm{SDS} 1 \mathrm{mmol}$ in various of $\mathrm{pH}$, ratio and flow rate. Mobile phase was filtered through $0.45 \mu \mathrm{m}$ pore filter and degassed using bath sonicator before use.

\section{Preparation of standard solutions}

The stock solution $1000 \mu \mathrm{g} / \mathrm{ml}$ of metformin and atenolol was processed separately by dissolving $10 \mathrm{mg}$ in $10 \mathrm{ml}$ methanol and 10 $\mathrm{mg}$ in $10 \mathrm{ml}$ methylene chloride for glimepiride in the volumetric flask. Each stock solution was diluted with methanol to achieve an intermediate solution of 20 and $100 \mu \mathrm{g} / \mathrm{ml}$, and then the intermediate solution was diluted again with methanol to produce the working standard solutions $(0.2-20 \mu \mathrm{g} / \mathrm{ml})$.

\section{Experimental design}

The optimization of HPLC condition was conducted by the experimental design approach, Box-Behnken Design (BBD) using Design-Expert 11.0 software. In the preliminary study, the mobile phase used was a mixture of acetonitrile-phosphate buffer 0.0125 M+SDS $1 \mathrm{mmol} \mathrm{pH} 4.00$ (25:75) with a flow rate $1.0 \mathrm{ml} / \mathrm{min}$. The independent variables in this study were the percentage of buffer composition in the mobile phase $\left(\mathrm{X}_{1}\right)$ that optimized at $70-80 \%, \mathrm{pH}$ of mobile phase $\left(\mathrm{X}_{2}\right)$ was optimized at 3.5-4.5, and flow rate $\left(\mathrm{X}_{3}\right)$ was optimized at $0.8-1.2 \mathrm{ml} / \mathrm{min}$. The responses as dependent variables were retention time, peak area, and resolution.

\section{Preparation of spiked plasma sample}

The preparation technique was modified from method of determining metfomin and glimepiride simultaneous in human serum [13]. Sample plasma was prepared by spiking working standard solutions of metformin, glimepiride and atenolol as internal standard. Aliquot of $750 \mu \mathrm{l}$ blank plasma was spiking with $500 \mu \mathrm{l}$ comprising mixture working solution of metformin and glimepiride, and $100 \mu \mathrm{l}$ of atenolol working solution. And then 3000 $\mu \mathrm{l}$ acetonitrile as extraction solvent was added. The solution was shaken for 10 seconds, next centrifuged for $10 \mathrm{~min}$ at $15.000 \mathrm{rpm} 4$ ${ }^{\circ} \mathrm{C}$. The supernatant was separated and made up $10.0 \mathrm{ml}$ with mobile phase addition. This solution was filtered with PVDF $0.45 \mu \mathrm{m}$ and 20 $\mu \mathrm{l}$ injected into HPLC system.

\section{System suitability test}

System suitability test (SST) was executed by injecting the analytes (metformin and glimepiride, and internal standard) in plasma each at concentration of $1000 \mathrm{ng} / \mathrm{ml}$ in six replicates. Parameters were observed included resolution (Rs>2), asymmetry (As $\leq 2)$, height equivalent to the theoretical plate (HETP $>2000)$, capacity factor $(\mathrm{k}>2)$, and \% coefficient variance of peak area and retention time $(\% \mathrm{CV}<2)[31]$.

\section{Validation of HPLC analysis}

Validation of the HPLC method is based on the European Medicines Agency (EMA) guidelines by assessing several validation parameters namely selectivity, accuracy, and precision, curve calibration, LLOQ, carryover, and stability [32].

\section{Selectivity}

Selectivity was recognized by comparing the chromatograms of the spiked samples and the blank plasma samples. For this purpose, the spiked sample of metformin, glimepiride, and atenolol as internal standard and blank plasma samples from six different sources were prepared and injected. Selectivity was analyzed to chromatographic interference around the retention times of metformin, glimepiride, and atenolol. Acceptance criteria for interfering component when the response is less than $20 \%$ of the lower limit of quantification for the analyte and $5 \%$ for the internal standard.

\section{Calibration curve}

Calibration curves were performed using blank plasma from a working standard solution. Calibration curves were assessed by preparing the calibration curve in the range of $15-1000 \mathrm{ng} / \mathrm{ml}$ for metformin and $10-1000 \mathrm{ng} / \mathrm{ml}$ for glimepiride. The internal standard of atenolol was added to each solution at a concentration of $1000 \mathrm{ng} / \mathrm{ml}$. Linear regression, slope, intercept, and \% recovery was calculated from each concentration. The acceptance criteria were seen from the recovery results must be in the range of $\pm 20 \%$ for LLOQ and $\pm 15 \%$ for other concentrations and at least $75 \%$ of calibration standards, with a minimum of six calibration standard levels, must satisfy the requirements.

\section{Accuracy and precision}

The within-run (single run) and between-run (in different run) accuracy and precision were carried out using 4 concentration levels covered in the calibration curve range, namely LLOQ, low ( $3 \times$ LLOQ), medium $(30-50 \%$ of the range of curves), and high $(75 \%$ of the upper calibration curve range) which 5 replication for each concentration. The concentration of metformin were $15 \mathrm{ng} / \mathrm{ml}, 45$ $\mathrm{ng} / \mathrm{ml}, 500 \mathrm{ng} / \mathrm{ml}$ and $750 \mathrm{ng} / \mathrm{ml}$, and for glimepiride were 10 $\mathrm{ng} / \mathrm{ml}, 30 \mathrm{ng} / \mathrm{ml}, 500 \mathrm{ng} / \mathrm{ml}$ and $750 \mathrm{ng} / \mathrm{ml}$ and using atenolol as internal standard at $1000 \mathrm{ng} / \mathrm{ml}$. The concentrations of metformin and glimepiride were determined using calibration curves acquired on the same days. Accuracy was approximated by comparing observed concentration with the nominal concentration as a mean percentage relative recovery, whereas precision was observed in $\% \mathrm{CV}$. The acceptance criteria for accuracy was \% error of the mean of observed concentration that it should be $15 \%$ at the nominal concentration, except for LLOQ which was $\leq 20 \%$. And the acceptance criteria for precision was the \%CV no more than $15 \%$ of the sample concentration and for LLOQ no more than $20 \%$ of the sample concentration.

\section{LLOQ}

The lowest concentration that can be quantified with acceptable accuracy and precision $(\mathrm{CV}<20 \%)$.

\section{Carry-over}

Carry-over was determined by injecting blank samples after a high concentration standard of metformin and glimepiride. The peak area at the retention time of metformin and glimepiride, and atenolol in the blank sample will not be greater than $20 \%$ of the lower limit of quantification (LLOQ) and 5\% for the internal standard.

\section{Stability}

Stability of metformin and glimepiride in the plasma were checked at low (45 ng/ml for metformin and $30 \mathrm{ng} / \mathrm{ml}$ for glimepiride) and high $(750 \mathrm{ng} / \mathrm{ml})$ quality control (QC) samples. Stability assessment comprised of stability of analyte in plasma after reconstitution then 
stored at room temperature $\left(25 \pm 2^{\circ} \mathrm{C}\right)$ for $24 \mathrm{~h}$ (autosampler stability), stability of analyte in plasma for $6 \mathrm{~h}$ at- $80{ }^{\circ} \mathrm{C}$, stability of analyte in plasma for $24 \mathrm{~h}$ at $-80^{\circ} \mathrm{C}$, and stability of analyte after 3 cycles of freeze $\left(-80 \pm 2{ }^{\circ} \mathrm{C}\right)$ and thaw $\left( \pm 25^{\circ} \mathrm{C}\right)$ (freeze and thaw stability).

\section{RESULTS AND DISCUSSION}

\section{Experimental design optimazitation}

Based on chemical structure, metformin and glimepiride have a distinctive polarity, therefore it was quite difficult to do separation by using HPLC. The use of experimental design by BBD was an alternative strategy to predict the optimum condition to separate these compounds. The effects of independent variables (composition of mobile phase, $\mathrm{pH}$ and flow rate) on the response variables (RT, Rs, peak area) from 17 experimental runs were analysed using statistical analysis ANOVA to obtain the polynomial equation to demonstrate the significant effect of independent variables on the response (dependent) variables. The complete results of responses values of BBD using independent variables are shown on table 1.

A good model is determined by the significance value of effect from each factor on the response variables $(\mathrm{p}<0.05)$. A good model should provide a value $\mathrm{R}^{2}>0.7$, which means the equation model can be used to predict the optimum condition. The adjusted coefficient of determination (Adj. $\left.R^{2}\right)>0.8$ represent that the polynomial equation provides a good model where the difference of Adj. $\mathrm{R}^{2}$ from the predicted $\mathrm{R}^{2}$ (pred. $\mathrm{R}^{2}$ ) should be less than 0.2 . The positive value from the equation denotes a positive correlation between independent and dependent variables, while the negative value evidence a counter-correlation in both variables [33-35].

Table 1: Design of experiment-based box-behnken design using independent variables of \% buffer $\left(\mathrm{X}_{1}\right)$, $\mathrm{pH}\left(\mathrm{X}_{2}\right)$, and flow rate $\left(\mathrm{X}_{3}\right)$ with response variables of retention time, peak area, and resolution used in HPLC method development for analysis of metformin and glimepiride

\begin{tabular}{|c|c|c|c|c|c|c|c|c|c|c|c|}
\hline \multirow[t]{2}{*}{ Run } & \multicolumn{3}{|c|}{ Independent variables (X) } & \multicolumn{2}{|c|}{ Responses (Y) } & \multirow[b]{2}{*}{ RT G $\left(Y_{3}\right)$} & \multirow[b]{2}{*}{$\begin{array}{l}\text { Peak Area } \\
\mathrm{M}\left(\mathrm{Y}_{4}\right)\end{array}$} & \multirow[b]{2}{*}{$\begin{array}{l}\text { Peak Area A } \\
\left(Y_{5}\right)\end{array}$} & \multirow[b]{2}{*}{$\begin{array}{l}\text { Peak Area } \\
G\left(Y_{6}\right)\end{array}$} & \multirow[b]{2}{*}{$\begin{array}{l}\text { Rs 1 } \\
\left(Y_{7}\right)\end{array}$} & \multirow[b]{2}{*}{$\operatorname{Rs} 2\left(\mathrm{Y}_{8}\right)$} \\
\hline & $\begin{array}{l}\text { \% } \\
\text { buffer } \\
\left(X_{1}\right)\end{array}$ & $\begin{array}{l}\mathbf{p H} \\
\left(\mathrm{X}_{2}\right)\end{array}$ & $\begin{array}{l}\text { FR } \\
\left(X_{3}\right)\end{array}$ & $\begin{array}{l}\text { RT M } \\
\left(Y_{1}\right)\end{array}$ & $\begin{array}{l}\text { RT A } \\
\left(Y_{2}\right)\end{array}$ & & & & & & \\
\hline 1 & 75 & 4.5 & 1.2 & 6.49 & 9.80 & 12.72 & 99394.00 & 26081.00 & 28350.50 & 10.36 & 7.05 \\
\hline 2 & 75 & 3.5 & 0.8 & 10.88 & 15.07 & 19.52 & 153676.00 & 38786.00 & 43720.50 & 8.87 & 7.10 \\
\hline 3 & 80 & 4.0 & 1.2 & 14.93 & 0 & 27.73 & 124030.00 & 0 & 27194.50 & 0 & 14.14 \\
\hline 4 & 70 & 4.0 & 1.2 & 3.85 & 4.78 & 10.82 & 93464.50 & 24216.50 & 23003.50 & 4.21 & 20.01 \\
\hline 5 & 75 & 3.5 & 1.2 & 7.02 & 9.69 & 12.72 & 101183.00 & 27269.00 & 21684.00 & 8.56 & 7.54 \\
\hline 6 & 80 & 4.0 & 0.8 & 23.41 & 22.36 & 43.97 & 30325.00 & 149135.00 & 39602.00 & 1.35 & 13.72 \\
\hline 7 & 70 & 4.0 & 0.8 & 5.79 & 7.20 & 16.54 & 140165.00 & 36806.00 & 48234.00 & 4.23 & 12.19 \\
\hline 8 & 70 & 4.5 & 1.0 & 4.61 & 5.75 & 13.01 & 113718.00 & 30292.00 & 38432.50 & 4.50 & 20.25 \\
\hline 9 & 75 & 4.0 & 1.0 & 7.99 & 11.82 & 15.44 & 103414.00 & 30586.00 & 30823.00 & 10.73 & 7.75 \\
\hline 10 & 75 & 4.0 & 1.0 & 8.00 & 11.83 & 15.42 & 103509.00 & 30710.00 & 28427.00 & 10.64 & 7.61 \\
\hline 11 & 75 & 4.0 & 1.0 & 8.00 & 11.82 & 15.40 & 107210.00 & 28289.00 & 28759.50 & 10.56 & 7.57 \\
\hline 12 & 75 & 4.0 & 1.0 & 8.02 & 11.86 & 15.41 & 110011.00 & 25758.50 & 27371.50 & 10.62 & 7.43 \\
\hline 13 & 80 & 4.5 & 1.0 & 16.79 & 17.69 & 34.29 & 121873.00 & 27862.00 & 31916.00 & 1.47 & 17.89 \\
\hline 14 & 80 & 3.5 & 1.0 & 23.25 & 17.78 & 33.84 & 100480.00 & 41279.00 & 30577.00 & 7.20 & 9.72 \\
\hline 15 & 75 & 4.5 & 0.8 & 9.84 & 14.88 & 19.37 & 141520.00 & 38335.50 & 43729.00 & 10.53 & 7.58 \\
\hline 16 & 75 & 4.0 & 1.0 & 8.04 & 11.89 & 15.41 & 109732.00 & 26984.00 & 24249.00 & 10.53 & 7.30 \\
\hline 17 & 70 & 3.5 & 1.0 & 4.69 & 5.75 & 13.20 & 120870.00 & 31691.00 & 20523.30 & 4.30 & 20.27 \\
\hline
\end{tabular}

The ANOVA analysis obtained from the independent variables $\left(\mathrm{X}_{1}\right.$, $\mathrm{X}_{2}$ and $\left.\mathrm{X}_{3}\right)$ and the retention time of metformin $\left(\mathrm{Y}_{1}\right)$ produced a polynomial equation as follows:

$1 / \mathrm{Y}_{1}=0.1248-0.0813 \mathrm{X}_{1}+0.0052 \mathrm{X}_{2}+0.0268 \mathrm{X}_{3}+0.0032 \mathrm{X}_{1} \mathrm{X}_{2}-$ $0.0157 \mathrm{X}_{1} \mathrm{X}_{3}+0.0005 \mathrm{X}_{2} \mathrm{X}_{3}+0.0107 \mathrm{X}_{1}{ }^{2}-0.0023 \mathrm{X}_{2}{ }^{2}-0.0000 \mathrm{X}_{3}{ }^{2}$ (Eq. 1)

The statistical analysis from Equation 1 shows Adj. $\mathrm{R}^{2}=0.9998$ and Pred. $\mathrm{R}^{2}=0.9967$, which means that it is within the acceptable criteria. Press value was 0.0002 , where the smaller value indicates a better model precision [34].
The response variable $\mathrm{Y}_{1}$ demonstrated the model was significant $(\mathrm{p}<0.05)$, this finding explained that the model could illustrate a significant effect of $X_{1}, X_{2}$ and $X_{3}$ on the response variable $Y_{1}$. of the three factors $\left(X_{1}, X_{2}\right.$ and $\left.X_{3}\right), X_{1}$ exhibited the strongest effect on $Y_{1}$, although $X_{2}$ and $X_{3}$ also showed some effects.

The interaction between the factors to the response can be seen from the 3D surface graph [36]. The 3D surface graph of metformin retention time was presented in fig. 2 .

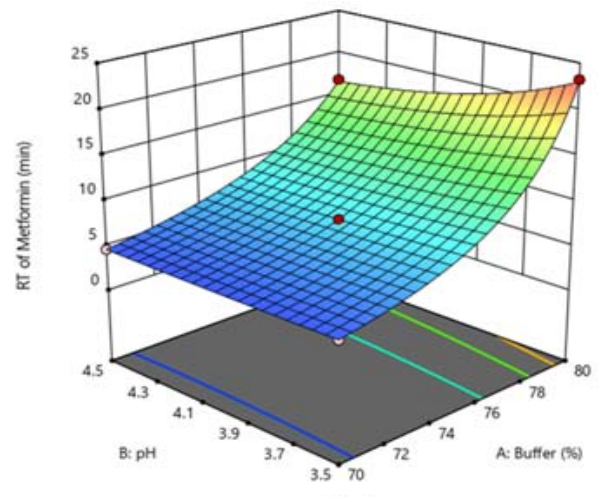

(A)

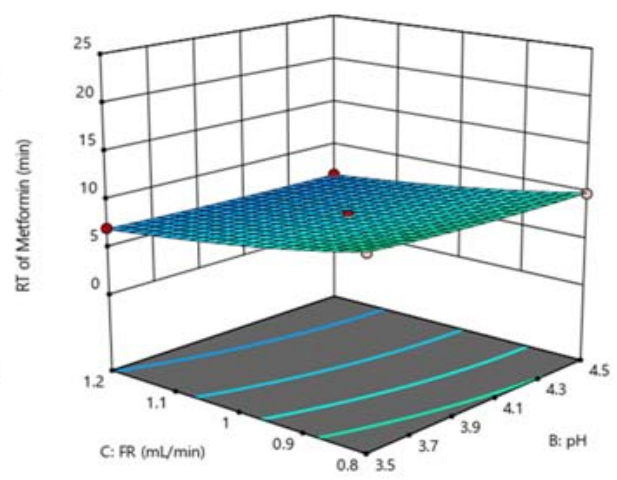

(B)

Fig. 2: The 3D surface graph of interaction between \%buffer $\left(\mathrm{X}_{1}\right)$ and $\mathrm{pH}\left(\mathrm{X}_{2}\right)(\mathrm{A})$; between $\mathrm{pH}\left(\mathrm{X}_{2}\right)$ and flow rate $\left(\mathrm{X}_{3}\right)(\mathrm{B})$ on retention time of metformin $\left(Y_{1}\right)$ 
The ANOVA analysis of atenolol retention time $\left(\mathrm{Y}_{2}\right)$ produced a polynomial equation as follows:

$$
\begin{gathered}
\mathrm{Y}_{2}=11.18+4.29 \mathrm{X}_{1}+0.0052 \mathrm{X}_{2}-4.41 \mathrm{X}_{3}-0.0233 \mathrm{X}_{1} \mathrm{X}_{2}- \\
4.98 \mathrm{X}_{1} \mathrm{X}_{3}+0.0750 \mathrm{X}_{2} \mathrm{X}_{3} \text { (Eq. 2) }
\end{gathered}
$$

Equation 2 generates $\mathrm{R}^{2}=0.8259$, Adj. $\mathrm{R}^{2}=0.7215$, Pred. $\mathrm{R}^{2}=0.1242$ and the difference value of Adj. $\mathrm{R}^{2}$ and Pred. $\mathrm{R}^{2}$ as 0.5973 . The ANOVA analysis shows $\mathrm{p}<0.05$ which means there was a significant effect between the factors and the observed response, although it did not satisfy the criteria as a good model as demonstrated by Adj. $\mathrm{R}^{2}<0.8$ and the difference between Adj. $\mathrm{R}^{2}$ and Pred. $\mathrm{R}^{2}>0.2$. The response $\mathrm{Y}_{2}$ was significantly affected by factor $\mathrm{X}_{1}$ and $\mathrm{X}_{3}$ (fig. 3).

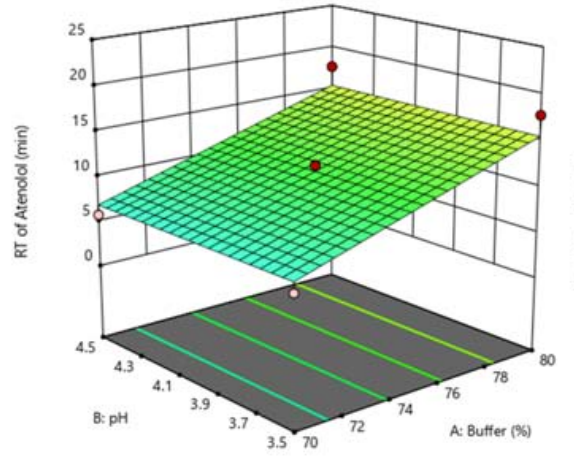

(A)
A quadratic polynomial equation for glimepiride retention time $\left(\mathrm{Y}_{3}\right)$ was described as follows:

$\ln \mathrm{Y}_{3}=2.74+0.4787 \mathrm{X}_{1}-0.0011 \mathrm{X}_{2}-0.2167 \mathrm{X}_{3}+0.0069 \mathrm{X}_{1} \mathrm{X}_{2}-0.0092$

$\mathrm{X}_{1} \mathrm{X}_{3}+0.0020 \mathrm{X}_{2} \mathrm{X}_{3}+0.3165 \mathrm{X}_{1}{ }^{2}-0.0015 \mathrm{X}_{2}{ }^{2}+0.0214 \mathrm{X}_{3}^{2}$ (Eq. 3)

Equation 3 yields $\mathrm{p}<0.05$ which means there was a significant correlation between the factor and the observed response with $\mathrm{R}^{2}=0.9999$, Adj. $\mathrm{R}^{2}=0.9998$, Pred. $\mathrm{R}^{2}=0.9990$, the difference between Adj. $\mathrm{R}^{2}$ and Pred. $\mathrm{R}^{2}$ was $<0.2$ and PRESS 0.0028. Retention time of glimepiride $\left(\mathrm{Y}_{3}\right)$ was affected by \%buffer $\left(\mathrm{X}_{1}\right)$ and flow rate $\left(\mathrm{X}_{3}\right)$ (fig. 4$)$.

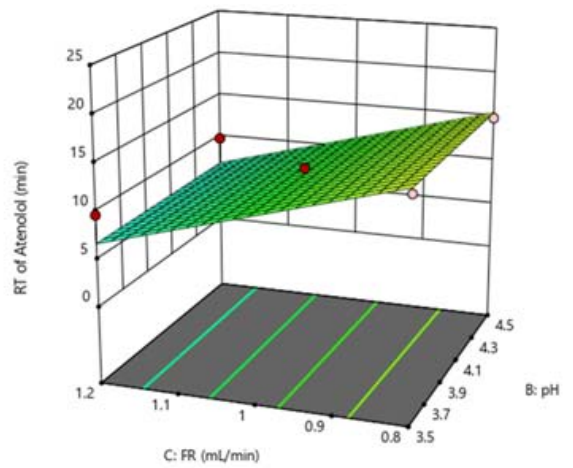

(B)

Fig. 3: The 3D surface graph of interaction between \%buffer $\left(X_{1}\right)$ and $\mathrm{pH}\left(\mathrm{X}_{2}\right)(\mathrm{A})$; between $\mathrm{pH}\left(\mathrm{X}_{2}\right)$ and flow rate $\left(\mathrm{X}_{3}\right)(\mathrm{B})$ on retention time of atenolol $\left(\mathrm{Y}_{2}\right)$

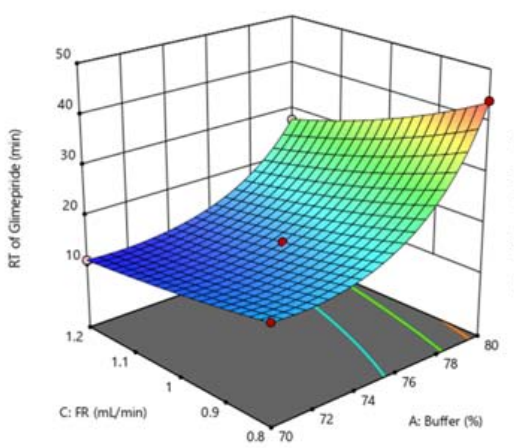

(A)

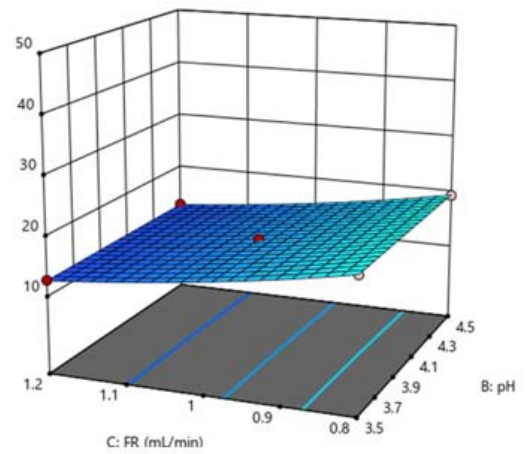

(B)

Fig. 4: The 3D surface graph of interaction between \%buffer $\left(X_{1}\right)$ and flow rate $\left(X_{3}\right)(A)$; between $\mathrm{pH}\left(\mathrm{X}_{2}\right)$ and flow rate $\left(\mathrm{X}_{3}\right)(\mathrm{B})$ on retention time of glimepiride $\left(\mathrm{Y}_{3}\right)$

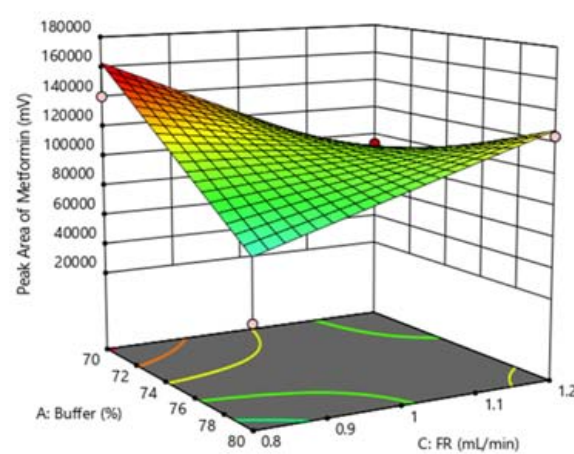

(A)

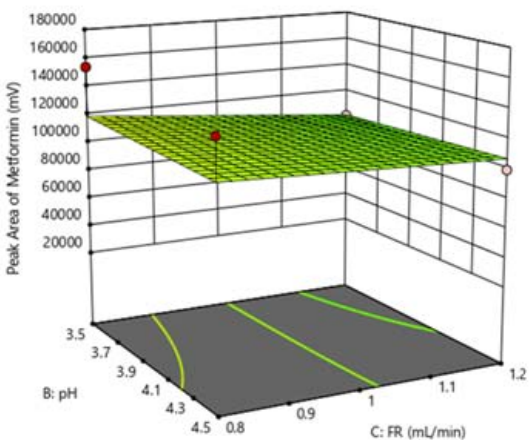

(B)

Fig. 5: The 3D surface graph of interaction between \%buffer $\left(X_{1}\right)$ and flow rate $\left(X_{3}\right)(A)$; between $p H\left(X_{2}\right)$ and flow rate $\left(X_{3}\right)(B)$ on the peak area of metformin $\left(\mathrm{Y}_{4}\right)$ 
Similarly, the equation for $\mathrm{Y}_{4}, \mathrm{Y}_{5}, \mathrm{Y}_{6}, \mathrm{Y}_{7}$ and $\mathrm{Y}_{8}$ were:

$\mathrm{Y}_{4}=1.103 \mathrm{E}+05-11438.65 \quad \mathrm{X}_{1}+36.98 \quad \mathrm{X}_{2}-5951.75 \quad \mathrm{X}_{3}+7136.42$ $\mathrm{X}_{1} \mathrm{X}_{2}+35101.38 \mathrm{X}_{1} \mathrm{X}_{3}+2591.87 \mathrm{X}_{2} \mathrm{X}_{3}\left(\mathrm{R}^{2}=0.5755\right.$, Adj. $\mathrm{R}^{2}=0.3208$ and Pred. $\mathrm{R}^{2}=-1.1445$ ) (Eq. 4)

The above model shows an insignificant effect $(p>0.05)$, its means the factors of $X_{1}, X_{2}$, and $X_{3}$ were not correlated with $Y_{4}$ [32]. The 3D surface graph of $\mathrm{Y}_{4}$ was presented in fig. 5.
$\sqrt{\mathrm{Y} 5}=177.54+7.09 \mathrm{X}_{1}-5.63 \mathrm{X}_{2}-61.06 \mathrm{X}_{3}-8.07 \mathrm{X}_{1} \mathrm{X}_{2}-87.49 \mathrm{X}_{1} \mathrm{X}_{3}-$ $0.6225 \mathrm{X}_{2} \mathrm{X}_{3}\left(\mathrm{R}^{2}=0.7847\right.$, Adj. $\mathrm{R}^{2} 0.6555$, Pred. $\left.\mathrm{R}^{2}=0.0773\right)$ (Eq. 5)

The ANOVA analysis of $Y_{5}$ had $p<0.05$, which means there was a significant effect between the factors and the observed response, although it did not satisfy the criteria as a good model as demonstrated by Adj. $\mathrm{R}^{2}<0.8$ and the difference between Adj. $\mathrm{R}^{2}$ and Pred. $\mathrm{R}^{2}>0.2$. The $\mathrm{Y}_{5}$ was affected by $\mathrm{X}_{1}$ and $\mathrm{X}_{3}$ (fig. 6).

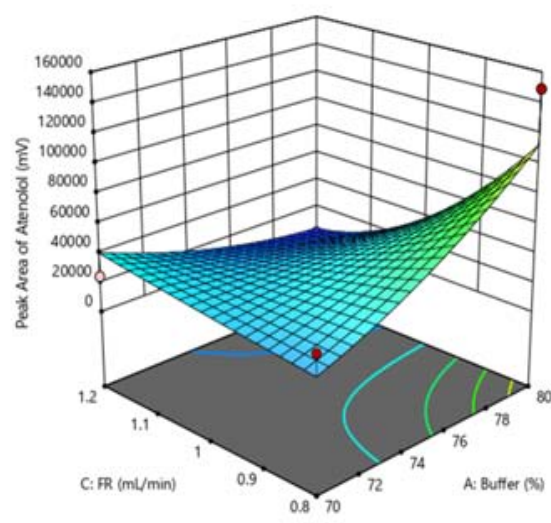

(A)

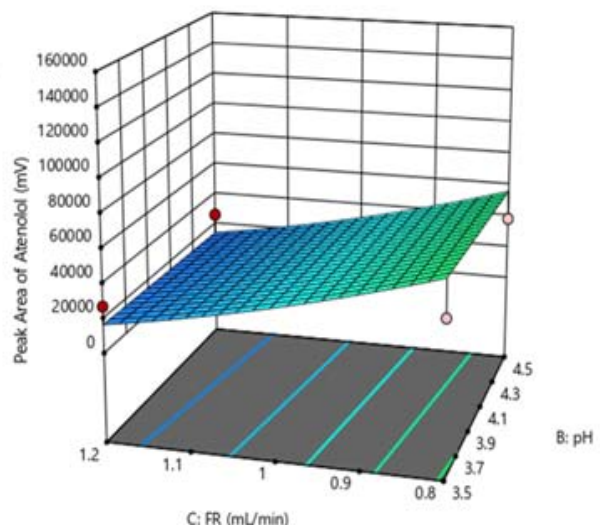

(B)

Fig. 6: The 3D surface graph of interaction between \%buffer $\left(\mathrm{X}_{1}\right)$ and flow rate $\left(\mathrm{X}_{3}\right)(\mathrm{A})$; between $\mathrm{pH}\left(\mathrm{X}_{2}\right)$ and flow rate $\left(\mathrm{X}_{3}\right)(\mathrm{B})$ on the peak area of atenolol $\left(\mathrm{Y}_{5}\right)$

$Y 6=27926.00-112.98 \quad X_{1}+3240.40 \quad X_{2}-9381.63 \quad X_{3}-4142.54$ $\mathrm{X}_{1} \mathrm{X}_{2}+3205.75 \quad \mathrm{X}_{1} \mathrm{X}_{3}+1664.50 \quad \mathrm{X}_{2} \mathrm{X}_{3}+1286.85 \quad \mathrm{X}_{1}^{2}+1149.35$ $\mathrm{X}_{2}{ }^{2}+5295.65 \mathrm{X}_{3}^{2}\left(\mathrm{R}^{2}=0.9537, \mathrm{Adj} . \mathrm{R}^{2}=0.8941\right.$ and Pred. $\left.\mathrm{R}^{2}=0.5631\right)$ (Eq. 6)
The response of $Y_{6}$ demonstrates a significant effect $(p<0.05)$. The factor of $X_{1}, X_{2}$ and $X_{3}$ were observed to have an effect on $Y_{5}$, but only $X_{2}$ and $X_{3}$ were found to act significantly (fig. 7).

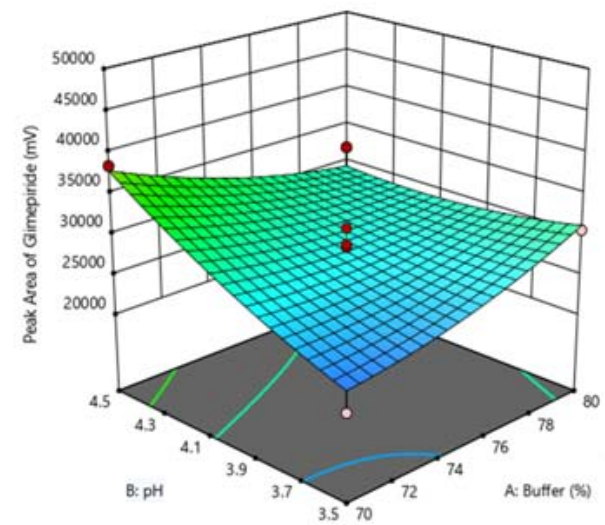

(A)

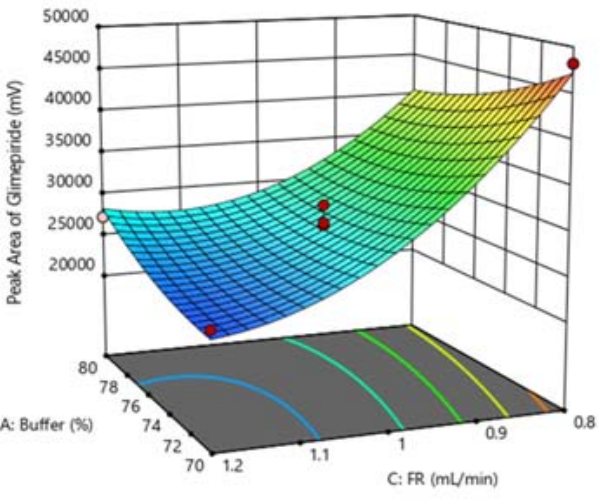

(B)

Fig. 7: The 3D surface graph of interaction between \%buffer $\left(X_{1}\right)$ and $\mathrm{pH}\left(\mathrm{X}_{2}\right)(\mathrm{A})$; between \%buffer $\left(\mathrm{X}_{1}\right)$ and flow rate $\left(\mathrm{X}_{3}\right)(\mathrm{B})$ on the peak area of glimepiride $\left(\mathrm{Y}_{6}\right)$

$\mathrm{Y} 7=10.62-0.9040 \quad \mathrm{X}_{1}-0.2571 \quad \mathrm{X}_{2}-0.2319 \quad \mathrm{X}_{3}-1.48 \quad \mathrm{X}_{1} \mathrm{X}_{2}-0.3325$ $\mathrm{X}_{1} \mathrm{X}_{3}+0.0337 \mathrm{X}_{2} \mathrm{X}_{3}-6.69 \mathrm{X}_{1}^{2}+0.4401 \mathrm{X}_{2}^{2}-1.48 \mathrm{X}_{3}^{2}\left(\mathrm{R}^{2}=0.9309\right.$, Adj. $\mathrm{R}^{2}=0.8421$ and Pred. $\left.\mathrm{R}^{2}=-0.1041\right)$ (Eq. 7)

$\mathrm{Y} 8=7.53-2.16 \mathrm{X}_{1}+1.02 \mathrm{X}_{2}+1.02 \mathrm{X}_{3}+2.05 \mathrm{X}_{1} \mathrm{X}_{2}-1.85 \mathrm{X}_{1} \mathrm{X}_{3}-0.2437$ $\mathrm{X}_{2} \mathrm{X}_{3}+8.60 \mathrm{X}_{1}{ }^{2}+0.9028 \mathrm{X}_{2}{ }^{2}-1.12 \mathrm{X}_{3}^{2}\left(\mathrm{R}^{2}=0.9389\right.$, Adj. $\mathrm{R}^{2}=0.8604$ and Pred. $\left.\mathrm{R}^{2}=0.0270\right)($ Eq. 8$)$

The $\mathrm{Y}_{7}$ and $\mathrm{Y}_{8}$ models demonstrated a significant correlation $(\mathrm{p}<0.05)$ between the factors and the observed response variables, which highly affected by $X_{1}$. The $3 D$ surface graph of $Y_{7}$ was presented in fig. 8, and for $\mathrm{Y}_{8}$ was presented in fig. 9.
Based on the eight equations above, the Design Expert 11.0 software can predict the optimum condition with selected criteria. These criteria were presented in table 2. And the optimum condition obtained from the Design Expert 11.0 software can be seen in fig. 10.

The predicted optimum condition was comprised of phosphate buffer at $72 \%$, pH at 4.3 with flow rate of $0.8 \mathrm{ml} / \mathrm{min}$. Fig. 11 showed chromatograph of metformin, atenolol and glimepiride produced using the optimum condition on plasma sample. It can be seen that the duration time of analysis was too long. Therefore, the flow rate was increased to $1.0 \mathrm{ml} / \mathrm{min}$ to shorten duration of the analysis. As shown on fig. 12 , by using flow rate at $1.0 \mathrm{ml} / \mathrm{min}$, the retention time 
of glimepiride became $14 \mathrm{~min}$, shorter than it from initial method using $0.8 \mathrm{ml} / \mathrm{min}$. And under these conditions, there was also did not find interfering peaks from the matrix. This condition was then chosen for system suitability test and validation method.

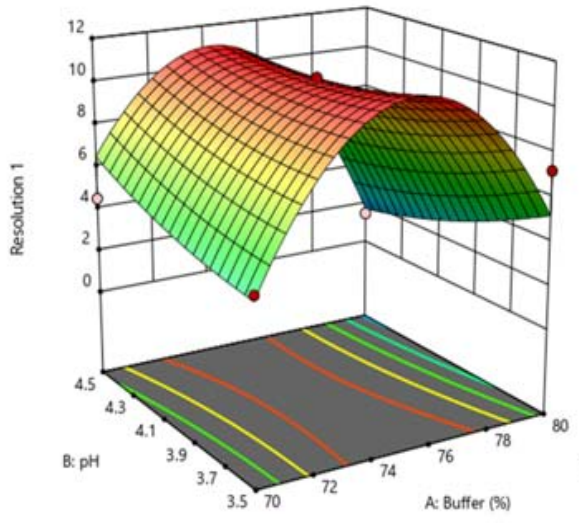

(A)

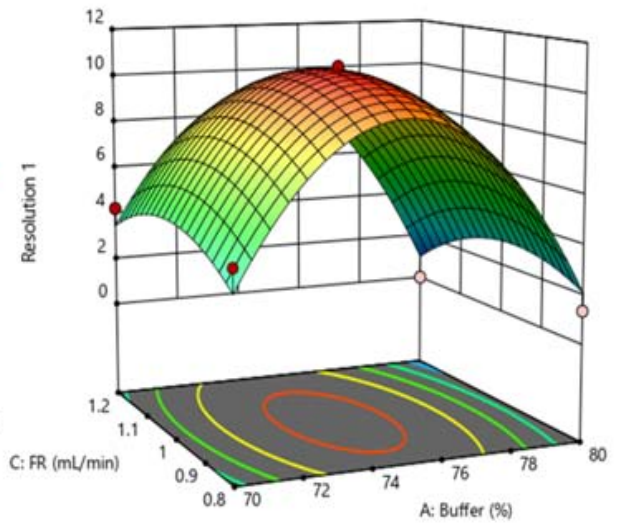

(B)

Fig. 8: The 3D surface graph of interaction between \%buffer $\left(X_{1}\right)$ and $p H\left(X_{2}\right)(A)$; between \%buffer $\left(X_{1}\right)$ and flow rate $\left(X_{3}\right)(B)$ on the resolution $1\left(\mathrm{Y}_{7}\right)$

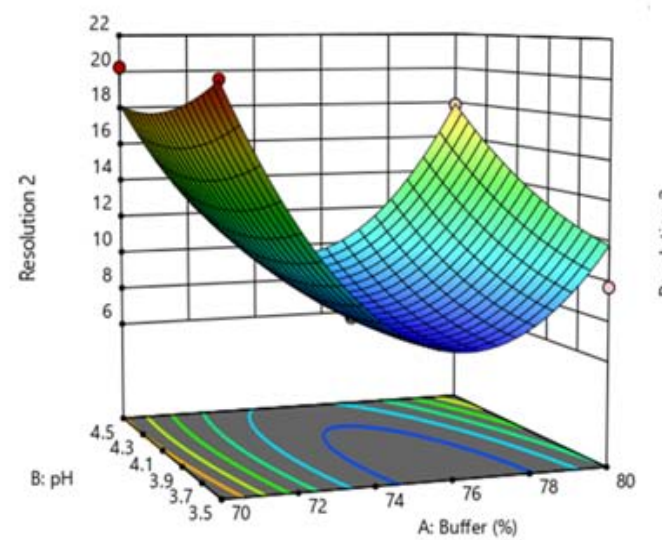

(A)

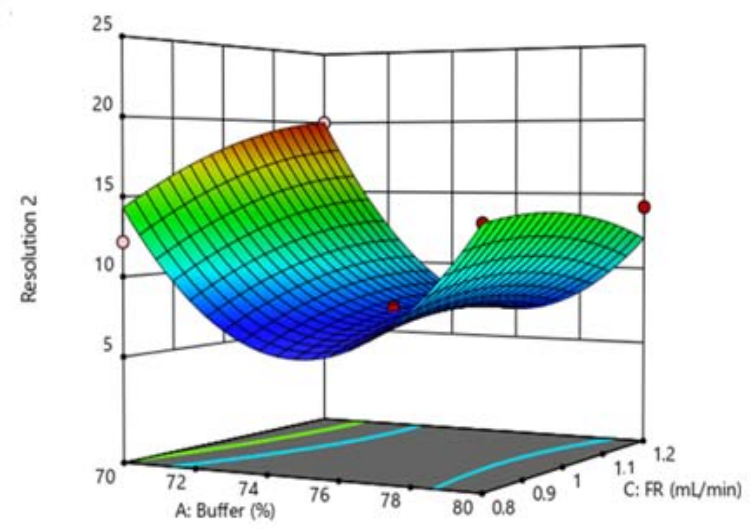

(B)

Fig. 9: The 3D surface graph of interaction between \%buffer $\left(X_{1}\right)$ and $p H\left(X_{2}\right)(A)$; between \%buffer $\left(X_{1}\right)$ and flow rate $\left(X_{3}\right)(B)$ on the resolution $2\left(\mathrm{Y}_{8}\right)$

Table 2: The criteria of factors and responses for determining the optimum condition

\begin{tabular}{lllll}
\hline Name & Goal & Lower limit & Upper limit & Importance* \\
\hline A: $\%$ Bufer & is in range & 70 & 80 & 3 \\
B: pH & is in range & 3.5 & 4.5 & 1.2 \\
C: FR & is in range & 0.8 & 9 & 3 \\
RT Metf & Minimize & 7 & 11 & 3 \\
RT Ate & is in range & 9.5 & 15.5 & 5 \\
RT Glim & is in range & 10 & 153676 \\
PA Metf & is in range & 30325 & 149135 \\
PA Ate & is in range & 0 & 48234 \\
PA Glim & Maximize & 20523.3 & 20 & 3 \\
Rs 1 & Minimize & 2 & 20 & 3 \\
Rs 2 & Minimize & 2 & 3 \\
\hline
\end{tabular}

*5: most important, 4: important, 3: middle important, 2: less important, 1: not important

Based on these results, it can be seen that the optimum conditions predicted by a statistical approach cannot always be applied directly, especially in multiple compounds analysis. Besides, a sample with the complex matrix was also considered in the optimization process because generally there will be produced a peak from the matrix that can interfere the signal. 


\begin{tabular}{|c|c|c|c|c|c|c|c|c|c|c|c|c|c|}
\hline Number & | \%Bufer | & $\mathrm{pH}$ & FR & RT Metf | & RT Ate & RT Glim | & LA Metf & LA Ate & LA Glim & Rs 1 & Rs 2 & Desirability & \\
\hline 1 & 71.881 & 4.313 & 0.800 & 6.259 & 9.743 & 15.500 & 140855.997 & 30590.964 & 48233.757 & 7.698 & 9.281 & 0.845 & Selected \\
\hline 2 & 71.851 & 4.310 & 0.800 & 6.236 & 9.688 & 15.486 & 141164.161 & 30326.125 & 48234.052 & 7.647 & 9.331 & 0.845 & \\
\hline 3 & 71.834 & 4.307 & 0.800 & 6.223 & 9.656 & 15.478 & 141347.156 & 30169.392 & 48233.966 & 7.617 & 9.361 & 0.845 & \\
\hline 4 & 71.895 & 4.317 & 0.800 & 6.269 & 9.766 & 15.500 & 140665.825 & 30705.855 & 48234.531 & 7.728 & 9.268 & 0.845 & \\
\hline 5 & 71.797 & 4.302 & 0.800 & 6.195 & 9.588 & 15.461 & 141730.405 & 29840.479 & 48234.030 & 7.552 & 9.425 & 0.845 & \\
\hline 6 & 71.763 & 4.298 & 0.800 & 6.171 & 9.525 & 15.447 & 142075.292 & 29539.218 & 48234.288 & 7.494 & 9.485 & 0.844 & \\
\hline 7 & 71.914 & 4.323 & 0.801 & 6.284 & 9.799 & 15.500 & 140388.076 & 30873.565 & 48234.050 & 7.771 & 9.249 & 0.844 & \\
\hline 8 & 71.904 & 4.329 & 0.800 & 6.286 & 9.782 & 15.500 & 140455.692 & 30786.947 & 48372.172 & 7.764 & 9.273 & 0.844 & \\
\hline 9 & 71.748 & 4.286 & 0.800 & 6.152 & 9.500 & 15.450 & 142371.970 & 29406.177 & 48128.140 & 7.444 & 9.492 & 0.844 & \\
\hline 10 & 71.909 & 4.333 & 0.800 & 6.293 & 9.792 & 15.499 & 140343.350 & 30837.179 & 48415.537 & 7.783 & 9.273 & 0.844 & \\
\hline
\end{tabular}

Fig. 10: The optimum condition of HPLC predicted by design expert 11.0 software

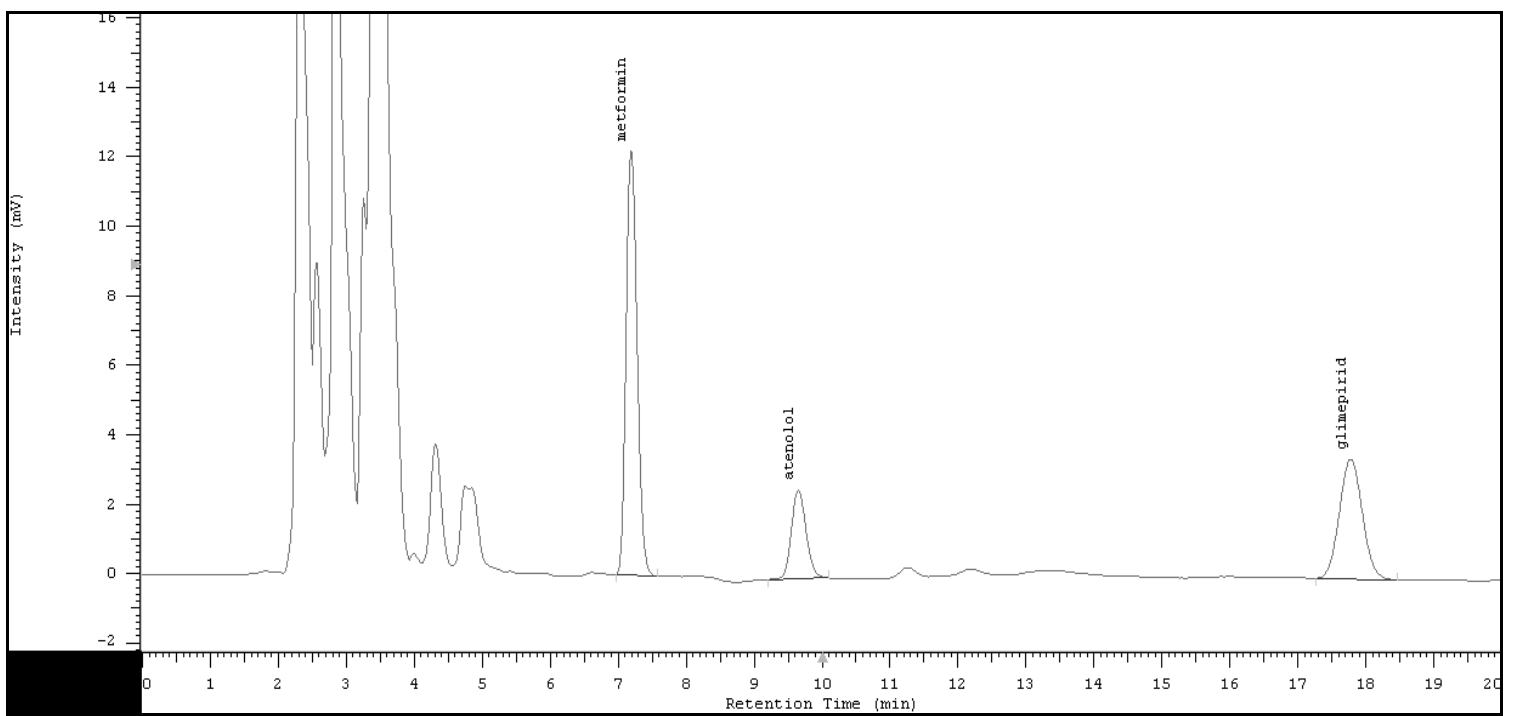

Fig. 11: HPLC chromatogram of metformin, glimepiride and atenolol $1000 \mu \mathrm{g} / \mathrm{ml}$, respectively in plasma matrix run at predicted optimum condition (buffer at $72 \%$, buffer $\mathrm{pH} 4.3$ with flow rate $0.8 \mathrm{ml} / \mathrm{min}$ )

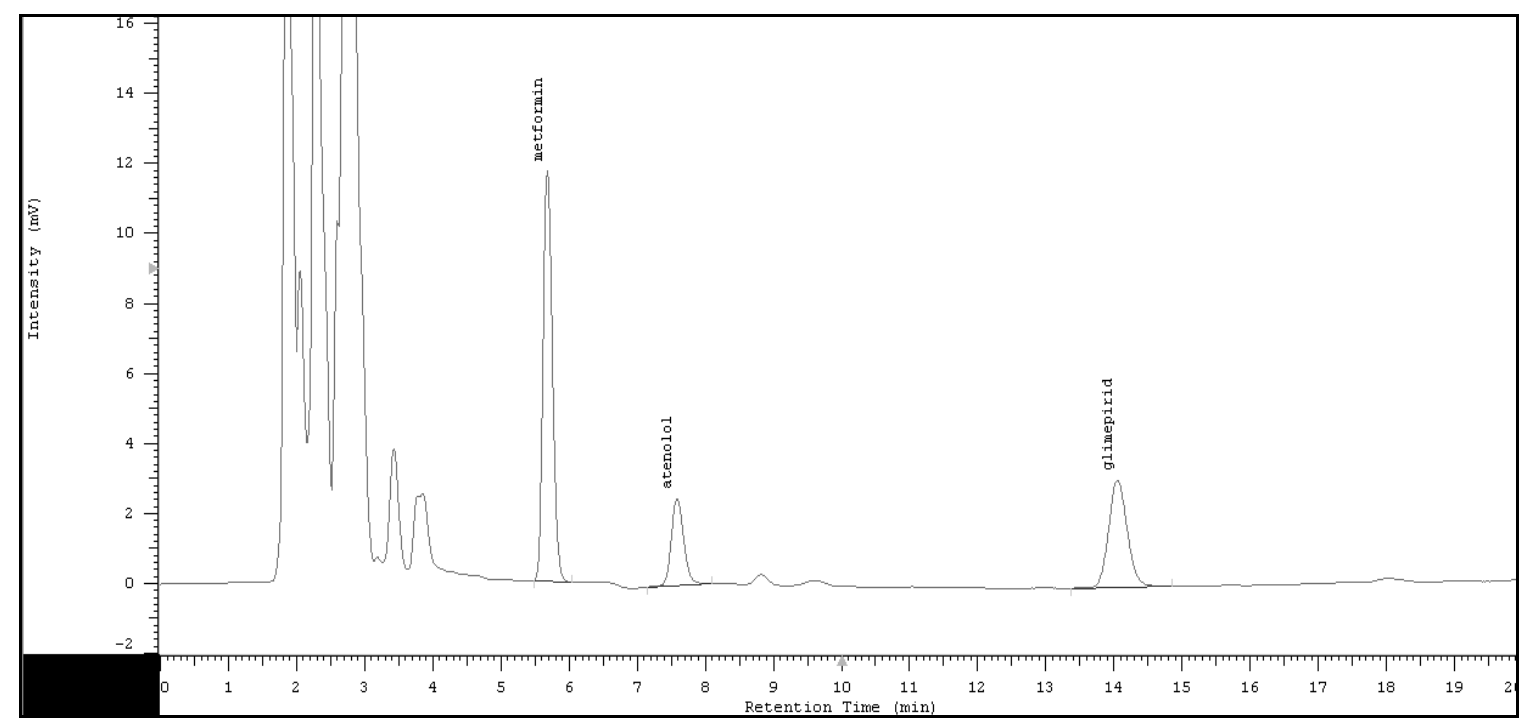

Fig. 12: HPLC chromatogram of metformin, glimepiride and atenolol $1000 \mu \mathrm{g} / \mathrm{ml}$, respectively in plasma matrix run at buffer at $72 \%$, buffer $\mathrm{pH} 4.3$ with flow rate $1.0 \mathrm{ml} / \mathrm{min}$

\section{System suitability test}

Some parameters of system suitability test (SST), namely resolution, asymmetry, height equivalent to the theoretical plate (HETP), $\mathrm{k}$, peak area, and retention time were evaluated. And based on the results of the SST of metformin and glimepiride, and atenolol as internal standard in spiked plasma showed that the condition of the optimized HPLC method satisfy the SST requirements i.e. resolution $>2$, asymmetry $\leq 2$, HETP $>2000, k>2$, and $\% C V$ of peak area and retention time $<2$. These results indicate that the HPLC system was running well and effectively for the quantitative analysis of metformin and glimepiride. The results of system suitability test are presented in table 3 . 
Table 3: System suitability test results of the optimum condition of the HPLC method

\begin{tabular}{lll}
\hline Parameters & Result \\
\hline Retention time of metformin & $0.00^{* *}$ \\
Retention time of glimepiride & $0.28^{* *}$ & Acceptance criteria \\
Retention time of atenolol & $0.07^{* *}$ & $\leq .44^{* *}$ \\
Peak area of metformin & $1.72^{* *}$ & $\leq 2$ \\
Peak area of glimepiride & $1.84^{* *}$ & $1.25 \pm 0.02^{*}$ \\
Peak area of atenolol & $1.35 \pm 0.04^{*}$ \\
Asymmetry of metformin & $1.18 \pm 0.02^{*}$ \\
Asymmetry of glimepiride & $6.11 \pm 0.04^{*}$ \\
Asymmetry of atenolol & $14.78 \pm 0.10^{*}$ \\
Resolution 1 (between metformin and atenolol) & $7987.33 \pm 77.55^{*}$ \\
Resolution 2 (between atenolol and glimepiride) & $11648.33 \pm 81.99^{*}$ \\
Number of theorical plates of metformin & $7227.50 \pm 104.50^{*}$ \\
Number of theorical plates of glimepiride & $2.76 \pm 0.00^{*}$ \\
Number of theorical plates of atenolol & $8.27 \pm 0.03^{*}$ \\
$k$ of metformin & $3.99 \pm 0.01^{*}$ \\
$k$ of glimepiride & & $>2$ \\
$k$ of atenolol & $>2$ \\
\hline
\end{tabular}

*Presented as mean value \pm SD **Presented as RSD

\section{Method validation}

\section{Selectivity}

The result of selectivity parameter showed that six individuals independent samples analyzed were satisfied with the selectivity requirements according to the EMA guidelines. Peak area of endogenous compounds at the retention time of analyte were less than $20 \%$ of the LLOQ of analyte and $<5 \%$ for IS (table 4 ). These indicate that the method was selective for analysis of metformin and glimepiride in the plasma sample.

Table 4: Selectivity data of metformin and glimepiride

\begin{tabular}{lll}
\hline Replication & $\mathbf{5 \%}$ of the AUC of IS: 1150 mV & Result \\
\hline Blank plasma 1 & 588 & $<20 \%$ and $<5 \%$ \\
Blank plasma 2 & 665 & $<20 \%$ and $<5 \%$ \\
Blank plasma 3 & 0 & $<20 \%$ and $<5 \%$ \\
Blank plasma 4 & 1092 & $<20 \%$ and $<5 \%$ \\
Blank plasma 5 & 0 & $<20 \%$ and $<5 \%$ \\
Blank plasma 6 & 1065 & $<20 \%$ and $<5 \%$ \\
\hline
\end{tabular}

*There was no signal in the retention time of metformin and glimepiride

\section{Linearity}

The linearity of the calibration curve of metformin and glimepiride was assessed from the coefficient of correlation (r-value) and the recovery of the nominal value. The linearity was explaining the correlation between analyte concentration (x-axis) and the ratio of AUC of analyte to AUC of internal standard (y-axis). The analyte concentrations used in this research were $15-1000 \mathrm{ng} / \mathrm{ml}$ for metformin and $10-1000 \mathrm{ng} / \mathrm{ml}$ for glimepiride (fig. 13). The method exhibited a good correlation with r-value more than of 0.99 (UNODC, 2009) i.e. 0.9993 for metformin and 0.9991 for glimepiride, respectively. The recovery results met the EMA requirements i.e. $<20 \%$ for $L L O Q$ and $<15 \%$ for other concentrations of the nominal value.
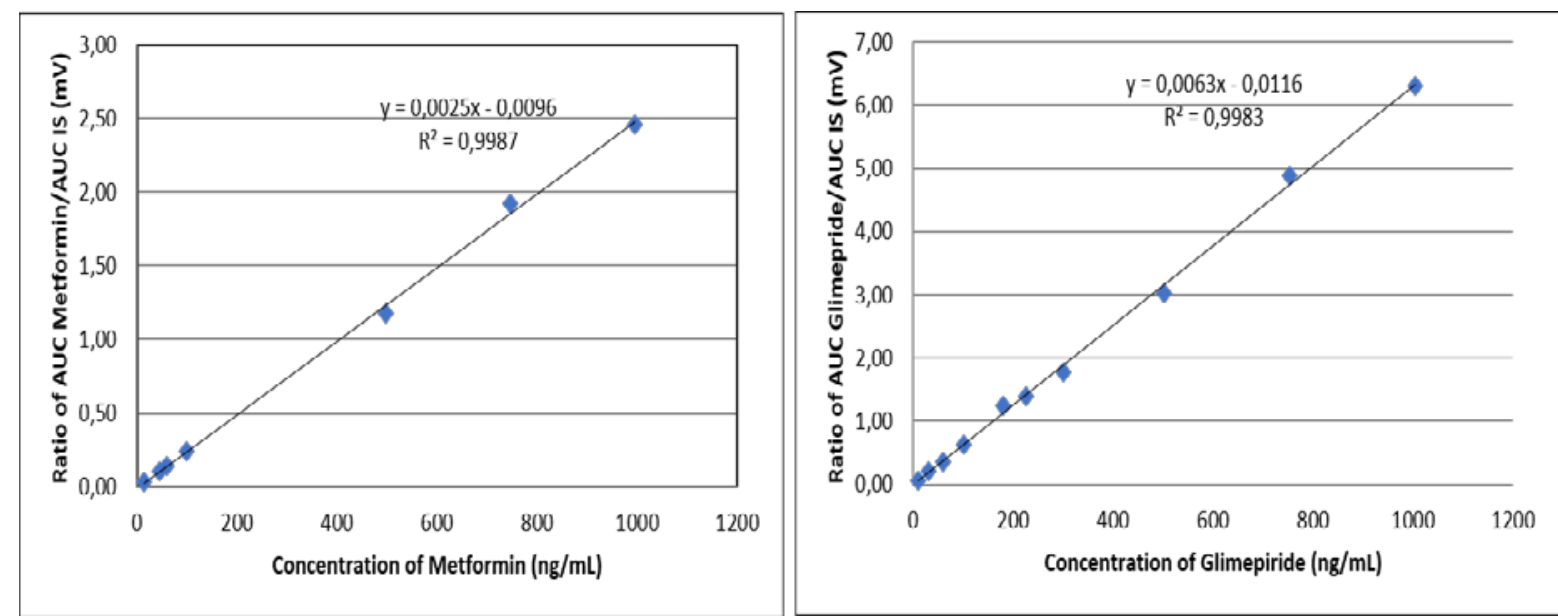

Fig. 13: The calibration curves of metformin and glimepiride between concentration of analyte ( $x$-axis) and ratio of the peak area of analyte to the peak area of IS (y-axis) 


\section{Accuracy and precision}

Accuracy and precision studies were conducted using 4 levels analyte concentration in spiked plasma namely at LLOQ, low, medium and high-quality control (QC) samples which 5 replications for metformin and glimepiride, respectively. The results of accuracy study both within-run and between-run accuracy were satisfied with the EMA guidelines requirements i.e. \%error of the mean of observed concentration was $\leq 15 \%$ of the nominal concentration, except for LLOQ which was $\leq 20 \%$. The results of the precision study also met the validation requirements based on EMA guidelines, namely $\% \mathrm{CV}$ values were $<15 \%$ for the QC samples and $<20 \%$ for LLOQ. The values obtained for within-run and between-run accuracy and precision of metformin and glimepiride were summarized in tables 5 and 6 . And the data for extraction recoveries were shown in table 7 .

Table 5: Within-run and between-run accuracy and precision data for metformin assays in spiked plasma $(n=5)$

\begin{tabular}{|c|c|c|c|c|c|c|c|c|}
\hline \multirow[t]{3}{*}{ Nominal concentration $(\mathrm{ng} / \mathrm{ml})$} & \multicolumn{4}{|c|}{ \% error } & \multicolumn{4}{|l|}{$\% \mathrm{CV}$} \\
\hline & \multicolumn{3}{|c|}{ Within (n=5) } & \multirow[t]{2}{*}{ Between (n=5) } & \multicolumn{3}{|c|}{ Within (n=5) } & \multirow[t]{2}{*}{ Between $(n=5)$} \\
\hline & Day 1 & Day 2 & Day 3 & & Day 1 & Day 2 & Day 3 & \\
\hline 14.92 & 16.08 & 2.72 & -1.65 & 5.72 & 1.81 & 9.00 & 2.45 & 8.72 \\
\hline 44.77 & 3.72 & 9.85 & 12.20 & 8.59 & 4.20 & 5.47 & 1.15 & 4.39 \\
\hline 497.50 & -3.09 & 1.55 & 10.69 & 3.05 & 2.87 & 0.33 & 3.21 & 6.55 \\
\hline 746.25 & 3.53 & 8.13 & 3.89 & 5.18 & 2.73 & 1.95 & 3.68 & 2.74 \\
\hline
\end{tabular}

Table 6: Within-run and between-run accuracy and precision data for glimepiride assays in spiked plasma $(n=5)$

\begin{tabular}{|c|c|c|c|c|c|c|c|c|}
\hline \multirow[t]{3}{*}{ Nominal concentration $(\mathrm{ng} / \mathrm{ml})$} & \multicolumn{4}{|c|}{ \%error } & \multicolumn{4}{|c|}{$\% \mathrm{CV}$} \\
\hline & \multicolumn{3}{|c|}{ Within (n=5) } & \multirow[t]{2}{*}{ Between $(n=5)$} & \multicolumn{3}{|c|}{ Within (n=5) } & \multirow[t]{2}{*}{ Between $(n=5)$} \\
\hline & Day 1 & Day 2 & Day 3 & & Day 1 & Day 2 & Day 3 & \\
\hline 10.03 & 7.43 & 11.47 & -9.10 & 3.45 & 2.19 & 0.83 & 0.04 & 9.64 \\
\hline 30.12 & -1.50 & -13.33 & 1.94 & -4.37 & 2.43 & 2.33 & 6.50 & 8.67 \\
\hline 501.95 & 0.57 & -5.76 & 9.43 & 1.53 & 2.42 & 5.74 & 1.34 & 7.57 \\
\hline 752.92 & -9.94 & 1.61 & -0.27 & -2.74 & 1.22 & 1.95 & 2.30 & 6.14 \\
\hline
\end{tabular}

Table 7: Recovery data for metformin and glimepiride assays in spiked plasma $(n=15)$

\begin{tabular}{|c|c|c|}
\hline Nominal concentration (ng/ml) & mean \pm SD of measurable concentration $(\mathrm{ng} / \mathrm{ml})$ & $\% \mathrm{CV}$ \\
\hline \multicolumn{3}{|l|}{ Metformin } \\
\hline 14.92 & $15.78 \pm 1.37$ & 8.69 \\
\hline 44.77 & $48.62 \pm 2.13$ & 4.39 \\
\hline 497.50 & $512.68 \pm 33.61$ & 6.55 \\
\hline 746.25 & $784.92 \pm 21.49$ & 2.74 \\
\hline \multicolumn{3}{|l|}{ Glimepiride } \\
\hline 10.03 & $10.47 \pm 1.81$ & 17.34 \\
\hline 30.12 & $28.85 \pm 2.50$ & 8.67 \\
\hline 501.95 & $504.85 \pm 35.15$ & 6.96 \\
\hline 752.92 & $728.44 \pm 44.00$ & 6.04 \\
\hline
\end{tabular}

\section{LLOQ}

The obtained LLOQ were $15 \mathrm{ng} / \mathrm{ml}$ for metformin and $10 \mathrm{ng} / \mathrm{ml}$ for glimepiride. These concentrations have to satisfy the EMA guidelines requirements, namely the value of the $\%$ error of recovery i. e $<20 \%$ and $\%$ recovery in the range of $80-120 \%$.

\section{Dilution integrity}

The results of the dilution integrity study have to satisfy the acceptance criteria i.e. accuracy and precision within $\pm 15 \%$. These results indicated the method can be used to analyze a sample over ULOQ concentration after the convenient dilution.

Table 8: The result of dilution integrity study of metformin and glimepiride

\begin{tabular}{|c|c|c|c|c|c|c|}
\hline \multirow[t]{2}{*}{ Dilution factor } & \multicolumn{3}{|l|}{ Metformin } & \multicolumn{3}{|l|}{ Glimepiride } \\
\hline & Concentration in plasma $(\mathrm{ng} / \mathrm{ml})$ & $\begin{array}{l}\text { Accuracy } \\
\text { (\% error) }\end{array}$ & $\begin{array}{l}\text { Precision } \\
\text { (\%CV) }\end{array}$ & Concentration in plasma $(\mathrm{ng} / \mathrm{ml})$ & $\begin{array}{l}\text { Accuracy } \\
\text { (\%error) }\end{array}$ & $\begin{array}{l}\text { Precision } \\
\text { (\%CV) }\end{array}$ \\
\hline $2 \mathrm{x}$ & 992.03 & -0.35 & 3.61 & 997.37 & -4.01 & 4.05 \\
\hline $5 x$ & 396.81 & 7.54 & 3.79 & 398.95 & 11.82 & 3.46 \\
\hline
\end{tabular}

\section{Carryover}

Carryover was analyzed by injecting a blank plasma after the higher concentration standard solution. There was no carryover detected in three blank samples, analyzed after the higher concentration standard solution. EMA guidelines requirement for carryover is the peak area at the retention time of analyte doesn't exceed $20 \%$ for LLOQ and 5\% for IS. Carryover study results can be seen in table 8.

Table 9: Carryover data of metformin and glimepiride

\begin{tabular}{|c|c|c|}
\hline Replication & $5 \%$ of the IS area: $1150 \mathrm{mV}$ & Result \\
\hline Blank plasma 1 & 606 & $<20 \%$ and $<5 \%$ \\
\hline Blank plasma 2 & 855 & $<20 \%$ and $<5 \%$ \\
\hline Blank plasma 3 & 0 & $<20 \%$ and $<5 \%$ \\
\hline
\end{tabular}

*There was no signal in the retention time of metformin and glimepiride 


\section{Stability}

A stability study was carried out to determine the stability of the analyte during the preparation and storage process. There was no significant degradation of metformin after the samples were stored under various conditions. Stability of glimepiride after stored at-80 ${ }^{\circ} \mathrm{C}$ for $6 \mathrm{~h}$ was assured. However, there was a significant decrease of glimepiride concentration after $24 \mathrm{~h}$ storage at $-80{ }^{\circ} \mathrm{C}$, the samples evaluation in the freeze and thaw stability, and the extracted samples keeping in the auto-sampler at $25{ }^{\circ} \mathrm{C}$ for $24 \mathrm{~h}$ (table 9). Glimepiride instability was estimated due to the chemical structure of glimepiride contain sulfonylurea bridges, carboxamides, $\beta$-lactam rings, and $\alpha-\beta$ unsaturated carbonyl systems that caused the drug impressionable to degradation by photolysis or hydrolysis [37].

The results of the stock solution stability showed that the stock solution from metformin was still stable for $56 \mathrm{~d}$. This was indicated by $\%$ error less than $15 \%$. i. e-3.61\% for $\mathrm{T}_{0}$ and $9.21 \%$ for $\mathrm{T}_{56}$. The results of stock solution stability of glimepiride showed an increased glimepiride concentration after $30 \mathrm{~d}$ of storage, the \%error of $\mathrm{T}_{0}$ was $1.43 \%$ and for $\mathrm{T}_{30}$ was $35.65 \%$. Methylene chloride which used to dissolve glimepiride was a very volatile solvent, so the stock solutions become more concentrated and the measured concentration becomes larger.

Table 10: Stability data for metformin and glimepiride assay in spiked plasma

\begin{tabular}{lllll}
\hline Stability study & & mean \pm SD of measurable concentration (ng/ml) & Accuracy (\%error) & Precision (\%CV) \\
\hline Metformin & & & & \\
$\mathrm{T}_{6}$ & Low QC & $49.53 \pm 3.04$ & 10.62 & 6.14 \\
& High QC & $782.23 \pm 17.83$ & 4.82 & 2.28 \\
$\mathrm{~T}_{24}$ & Low QC & $42.14 \pm 3.15$ & -5.88 & 7.48 \\
& High QC & $822.44 \pm 17.32$ & 10.21 & 2.11 \\
Freeze and Thaw & Low QC & $43.09 \pm 4.68$ & -3.77 & 10.87 \\
& High QC & $781.79 \pm 45.95$ & 4.76 & 5.88 \\
auto-sampler & 995.00 ng/ml & $951.57 \pm 5.17$ & -4.36 & 0.54 \\
Glimepiride & & & & 3.64 \\
$\mathrm{~T}_{6}$ & Low QC & $28.77 \pm 1.05$ & -4.76 & 7.55 \\
& High QC & $709.07 \pm 53.50$ & -6.11 & 11.41 \\
$\mathrm{~T}_{24}$ & Low QC & $20.40 \pm 2.33$ & -32.46 & 2.23 \\
& High QC & $593.79 \pm 13.24$ & -21.38 & 6.78 \\
Freeze and Thaw & Low QC & $18.89 \pm 1.28$ & -37.48 & 5.27 \\
auto-sampler & High QC & $623.11 \pm 32.83$ & -17.50 & 31.47 \\
\hline
\end{tabular}

The research using LC-MS/MS was very sensitive methods and produced a very low of LOQ, but the high of operational cost caused a problem in the laboratory. The method in this study has several advantages compared to the previously developed HPLC method, namely this study can reduce the number of SDS usage, so it can reduce the negative effect of SDS on the column. Based on the cost, this method was more cost-effective because the preparation technique carried out by protein precipitation compared to using the SPE technique. LOQ value in this study smaller compared to other research who also carried out the sample preparation using the protein precipitation technique $[13,18]$. The comparison of the new method and the previous methods that have been developed were summarized in table 11.

The method developed in this study was still in vitro, it will be better in further research conducted in vivo study, so the metabolic compounds of metformin and glimepiride can be evaluated. Furthermore, it is necessary to conduct a study that causes glimepiride instability, so it can be corrected when applying to the bioavailability and bioequivalence study.

Table 11: Summary of the simultaneous determination of metformin and glimepiride in plasma

\begin{tabular}{|c|c|c|c|c|c|}
\hline \multirow{2}{*}{ Parameters } & \multicolumn{4}{|l|}{ HPLC } & \multirow{2}{*}{$\begin{array}{l}\text { LC-MS/MS } \\
\text { Previous method-4 [17] }\end{array}$} \\
\hline & $\begin{array}{l}\text { The method in this } \\
\text { study }\end{array}$ & $\begin{array}{l}\text { Previous method-1 } \\
\text { [12] }\end{array}$ & $\begin{array}{l}\text { Previous } \\
\text { method-2 [13] }\end{array}$ & $\begin{array}{l}\text { Previous method- } \\
3 \text { [14] }\end{array}$ & \\
\hline Linear range & $\begin{array}{l}\text { Metformin: } 15-1000 \\
\text { ng/ml } \\
\text { Glimepiride: } 10-1000 \\
\text { ng/ml }\end{array}$ & $\begin{array}{l}\text { Metformin: 50-2000 } \\
\text { ng/ml } \\
\text { Glimepiride: } 25-1000 \\
\text { ng/ml }\end{array}$ & $\begin{array}{l}\text { Metformin: } 0.25- \\
25 \mu \mathrm{g} / \mathrm{ml} \\
\text { Glimepiride: } 0.5- \\
50 \mu \mathrm{g} / \mathrm{ml}\end{array}$ & $\begin{array}{l}\text { Metformin: } 2.5-100 \\
\mu \mathrm{g} / \mathrm{ml} \\
\text { Glimepiride: } 2.5- \\
100 \mu \mathrm{g} / \mathrm{ml}\end{array}$ & $\begin{array}{l}\text { Metformin: } 10-10000 \mathrm{ng} / \mathrm{ml} \\
\text { Glimepiride: } 4-4000 \mathrm{ng} / \mathrm{ml}\end{array}$ \\
\hline LOQ & $\begin{array}{l}\text { Metformin: } 15 \mathrm{ng} / \mathrm{ml} \\
\text { Glimepiride: } 10 \\
\mathrm{ng} / \mathrm{ml}\end{array}$ & $\begin{array}{l}\text { Metformin: } 5 \mathrm{ng} / \mathrm{ml} \\
\text { Glimepiride: } 7.5 \mathrm{ng} / \mathrm{ml}\end{array}$ & $\begin{array}{l}\text { Metformin: } 33 \\
\text { ng/ml } \\
\text { Glimepiride: } 49 \\
\text { ng/ml }\end{array}$ & $\begin{array}{l}\text { Metformin: } 180 \\
\text { ng/ml } \\
\text { Glimepiride: } 350 \\
\text { ng/ml }\end{array}$ & $\begin{array}{l}\text { Metformin: } 10 \mathrm{ng} / \mathrm{ml} \\
\text { Glimepiride: } 4 \mathrm{ng} / \mathrm{ml}\end{array}$ \\
\hline Mobile phase & $\begin{array}{l}\text { ACN: buffer } \mathrm{KH}_{2} \mathrm{PO}_{4} \\
0.0125 \mathrm{M}+\mathrm{SDS} 1 \\
\mathrm{mmol} \mathrm{pH} 4.3 \\
(28: 72 \%, \mathrm{v} / \mathrm{v})\end{array}$ & $\begin{array}{l}2 \text { mmol SDS in ACN: } \\
\text { buffer } \mathrm{KH}_{2} \mathrm{PO}_{4} 0.0125 \\
\mathrm{M} \mathrm{pH} 7.3(37.5: 62.5 \% \text {, } \\
\text { v/v) }\end{array}$ & $\begin{array}{l}\text { Methanol: water } \\
\text { pH } 3.0(90: 10 \% \text {, } \\
\text { v/v) }\end{array}$ & $\begin{array}{l}\text { Methanol: buffer } \\
\mathrm{KH}_{2} \mathrm{PO}_{4} 0.025 \mathrm{M} \mathrm{pH} \\
3.2(85: 15 \%, \mathrm{v} / \mathrm{v})\end{array}$ & $\begin{array}{l}\text { Gradient elution of methanol } \\
\text { (containing } 5 \mathrm{mmol} / \mathrm{l} \\
\text { ammonium acetate) and } 5 \\
\text { mmol/l aqueous ammonium } \\
\text { acetate }\end{array}$ \\
\hline $\begin{array}{l}\text { Stationary } \\
\text { phase }\end{array}$ & $\begin{array}{l}\text { Ascentis® Phenyl } \\
\text { C18 (250 } \\
\text { x 4,6 mm i.d.; } 5 \mu \mathrm{m})\end{array}$ & $\begin{array}{l}\text { C18 Supelco analytical } \\
\text { column }(250 \times 4,6 \mathrm{~mm} \\
\text { i.d., } 5 \mu \mathrm{m})\end{array}$ & $\begin{array}{l}\text { Purospher }{ }^{\circledR} \text { Star } \\
\text { C18 }(25 \times 0,46 \mathrm{~cm} \\
\text { i.d., } 5 \mu \mathrm{m})\end{array}$ & $\begin{array}{l}\text { MAGELLEN 5U C18 } \\
(150 \times 4.60 \mathrm{~mm} ., 5 \\
\mu \mathrm{m})\end{array}$ & $\begin{array}{l}\mathrm{CN} \text { column }(150 \times 4.6 \mathrm{~mm}, 5 \\
\mu \mathrm{m})\end{array}$ \\
\hline $\begin{array}{l}\text { Sample } \\
\text { preparation } \\
\text { techniques }\end{array}$ & $\begin{array}{l}\text { protein precipitation } \\
\text { using ACN }\end{array}$ & SPE & $\begin{array}{l}\text { protein } \\
\text { precipitation } \\
\text { using ACN }\end{array}$ & $\begin{array}{l}\text { protein } \\
\text { precipitation using } \\
\text { methanol }\end{array}$ & $\begin{array}{l}\text { protein precipitation using } \\
\text { methanol }\end{array}$ \\
\hline Flow rate & $1.0 \mathrm{ml} / \mathrm{min}$ & $1.0 \mathrm{ml} / \mathrm{min}$ & $1.0 \mathrm{ml} / \mathrm{min}$ & $1.0 \mathrm{ml} / \mathrm{min}$ & $0.8 \mathrm{ml} / \mathrm{min}$ \\
\hline Wavelength & $210 \mathrm{~nm}$ & $225 \mathrm{~nm}$ & $231 \mathrm{~nm}$ & $234 \mathrm{~nm}$ & - \\
\hline
\end{tabular}




\section{CONCLUSION}

The design expert of Box-Behnken could be used for optimization HPLC conditions to analyze metformin, glimepiride and atenolol as an internal standard for spiked plasma samples. The predicted condition produced from BBD, sometimes has to adjusted in order to get the optimum time of analysis. The optimum condition of HPLC resulted from this research was comprised of the mixture 28\%:72\% of acetonitrile-phosphate buffer $0.0125 \mathrm{M}+\mathrm{SDS} 1 \mathrm{mmol}$ as mobile phase, $\mathrm{pH}$ adjusted at 4.3 and flow rate at $1.0 \mathrm{ml} / \mathrm{min}$. This optimum condition was valid to quantify metformin and glimepiride in spiked plasma by considering the storage time of plasma samples.

\section{ACKNOWLEDGMENT}

The authors acknowledge to Universitas Gadjah Mada-Indonesia that already giving research funding in the fiscal year 2019 awarded to Endang Lukitaningsih.

\section{AUTHORS CONTRIBUTIONS}

HI, EL, and SM performed research activity, compiled data, and prepared manuscript.

\section{CONFLICT OF INTERESTS}

There are no conflicts of interest.

\section{REFERENCES}

1. Wells DA. High throughput bioanalytical sample preparation: methods and automation strategies. $1^{\text {st }}$. Amsterdam: Elsevier; 2003.

2. WHO. The top 10 causes of death; 2018. Available from: http://www.who.int/news-room/fact-sheets/detail/the-top10-causes-of-death. [Last accessed on 07 Aug 2018]

3. Kupsal K, Mudigonda S, Nvbk S, Neelala K. Review: metformin combinatorial therapy for type 2 diabetes mellitus. J Metab Syndr 2016;5:1-8.

4. Hermann LS, Lindberg G, Lindblad U, Melander A. Efficacy, effectiveness and safety of sulphonylurea-metformin combination therapy in patients with type 2 diabetes. Diabetes Obes Metab 2002;4:296-304.

5. Davis SN. Chapter 60. insulin, oral hypoglycemic agents, and the pharmacology of the endocrine pancreas. In: Brunton L, Lazo J, Parker L. editors. Goodman and Gilman's the Pharmacological Basis of Therapeutics. 11 ${ }^{\text {the }}$. USA: McGraw Hill; 2006. p. 1634-40.

6. Draeger E. Clinical profile of glimepiride. Diabetes Res Clin Pract 1995;28:S139-46.

7. Fachi MM. Bioanalytical methods for the detection of antidiabetic drugs: a review. Bioanalysis 2017;9:2015-25.

8. Marangon E, Posocco B, Mazzega E, Toffoli G. Development and validation of high-performance liquid chromatography-tandem mass spectrometry method for the simultaneous determination of irinotecan and its main metabolites in human plasma and its application in a clinical pharmacokinetic study. PLOS One 2015;10:1-18.

9. Tutunji M, Jarrar O, Musameh M, Alam SM, Quamruzaman, Dham R. Bioequivalence evaluation of two brands of cefaclor $500 \mathrm{mg}$ capsules: quantification of cefaclor using solid-phase extraction technique. J Clin Pharm 2001;26:149-53.

10. Prabu SL, Suriyaprakash TNK. Extraction of drug from the biological matrix: a review. In: Naik GR. editor. Applied Biological: Engineering-Principles and Practice. London: Intech Open Access Publisher; 2012. p. 479-503.

11. Abro K, Memon N, Bhanger MI, Perveen S, Panhwar A. Comparative study of electrospray and atmospheric pressure chemical ionization with liquid chromatography-mass spectrometry for quantification of five antihyperglycemic agents utilizing monolithic column. Anal Lett 2012;45:1947-59.

12. AbuRuz S, Millership J, McElnay J. The development and validation of liquid chromatography method for the simultaneous determination of metformin and glipizide, gliclazide, glibenclamide or glimperide in plasma. J Chromatogr B 2005;817:277-86.

13. Arayne MS, Sultana N, Tabassum A. RP-LC simultaneous quantitation of co-administered drugs for (non-insulin dependent) diabetic mellitus induced dyslipidemia in active pharmaceutical ingredient, pharmaceutical formulations and human serum with uv-detector. Clin Chim Acta 2013;425:54-61.

14. Sebaiy MM, Sobhy the -Adl, Baraka MM, Hassan AA. Rapid RPHPLC method for simultaneous estimation of metformin, pioglitazone, and glimepiride in human plasma. Acta Chromatogr 2018;1-6. Doi:10.1556/1326.2018.00515

15. Elzanfaly ES, Abdel Gawad S. Simultaneous quantification of ramipril, glimepiride and metformin in human plasma by ultraperformance liquid chromatography-tandem mass spectrometry. J Appl Pharm Sci 2017;7:62-9.

16. Fachi MM, Cerqueira LB, Leonart LP, Francisco TMG, Pontarolo R. Simultaneous quantification of antidiabetic agents in human plasma by a UPLC-QToF-MS method. PLOS One 2016;11:1-17.

17. Jing B. Liquid chromatography-electrospray ionization tandem mass spectrometry for simultaneous determination of metformin and glimepiride in beagle dog plasma and bioequivalence study. Chem Res Chin Univ 2012;28:399-405.

18. Polagani SR, Pilli NR, Gajula R, Gandu V. Simultaneous determination of atorvastatin, metformin and glimepiride in human plasma by LC-MS/MS and Its application to a human pharmacokinetic study. J Pharm Anal 2013;3:9-19.

19. Sengupta P. LC-MS-MS development and validation for simultaneous quantitation of metformin, glimepiride and pioglitazone in human plasma and its application to a bioequivalence study. Chromatographia 2009;69:1243-50.

20. Gandjar IG, Rohman A. Drug analysis by spectrophotometry and chromatography. Yogyakarta: Pustaka Pelajar; 2012.

21. Patil P. HPLC method development-a review. J Pharm Res Educ 2017;1:243-60.

22. Brouder A, Tietje C. editors. Handbook of Transnational Economic Governance Regimes. Netherlands: Brill; 2009.

23. Ferreira SLC. Review: box-behnken design: an alternative for the optimization of analytical methods. Anal Chim Acta 2007;597:179-86.

24. Sahu P. An overview of experimental designs in HPLC method development and validation. J Pharm Biomed Anal 2018;147:590-611.

25. Gopi G, Kannan K. Formulation development and optimization of nateglinide-loaded ethyl cellulose nanoparticles by boxbehnken design. Int J Pharm Pharm Sci 2015;7:310-5.

26. Saha C, Gupta NV, Chandan RS, Priya S. The development of validated indicating LC-MS method for the determination of tenovir disoproxil fumarate using quality by design approach. Int J Appl Pharm 2019;11:406-17.

27. Radha S, Sridevi A, Prasad N, Narasimha G. Statistical and kinetic studies of acid protease by aspergillus spp. isolated from soil contaminated with abattoir waste. Int J Pharm Pharm Sci 2018;10:72-9.

28. Beg S, Kohli K, Swain S, Hasnain MS. Development and validation of RP-HPLC method for quantitation of amoxicillin trihydrate in bulk and pharmaceutical formulations using boxbehnken experimental design. J Liq Chromatogr Relat Technol 2012;3:393-406.

29. Mittal A, Imam A, Parmar S, Gilani S, Taleuzzaman M. Design of experiment based optimized RP-HPLC method for simultaneous estimation of amlodipine and valsartan in bulk and tablet formulations. Austin J Anal Pharm Chem 2015;2:1057-62.

30. Sahu PK, Swain S, Prasad G, Panda J, Murthy Y. RP-HPLC method for determination of metaxalone using box-behnken experimental design. J Appl Biopharm Pharmacokinet 2014;2:40-9.

31. Snyder L, Kirkland J, Dolan JW. Introduction to modern liquid chromatography. $3^{\text {rd. }}$. New Jersey: Wiley; 2010.

32. EMA, Guideline on Bioanalytical Method Validation, European Medicines Agency; 2011.

33. Prabaningdyah NK, Riyanto S, Rohman A, Siregar C. Application of HPLC and response surface methodology for simultaneous determination of curcumin and desmethoxy curcumin in curcuma syrup formulation. J Appl Pharm Sci 2017;7:58-64.

34. Purba NB, Rohman A, Martono S. The optimization of HPLC for quantitative analysis of acid orange 7 and sudan II in cosmetic 
products using box behnken design. Int J Appl Pharm 2019;11:130-7.

35. Siregar C, Prabaningdyah NK, Choiri S, Riyanto S, Rohman A Optimization of HPLC using central composite design for determination of curcumin and demethoxycurcumin in tablet dosage form. Dhaka Univ J Pharm Sci 2017;16:137-45.
36. Zhao LC. Response surface modeling and optimization of accelerated solvent extraction of four lignans from fructus schisandrae. Molecules 2012;17:3618-29.

37. Bansal G, Singh M, Jindal KC, Singh S. LC-UV-PDA and LC-MS studies to characterize degradation products of glimepiride. J Pharm Biomed Anal 2008;48:788-95. 